\title{
Hubungan Antara Tingkat Kecemasan Pada Ibu Hamil Trimester III Dengan Skor Prenatal Attachment di Praktik Mandiri Bidan Rina Malang
}

\author{
Rizkatul Baro'ah ${ }^{1 *}$, Miftahul Jannah ${ }^{2}$, Era Nurisa $\mathbf{W}^{3}$, Diadjeng Setya $\mathrm{W}^{2}$ \\ 1 Program Studi S1 Kebidanan, Fakultas Kedokteran, Universitas Brawijaya, \\ Email: rizkatulbaroah@gmail.com, Tlp : +6287763199098 \\ 2 Program Studi S1 Kebidanan, Fakultas Kedokteran, Universitas Brawijaya \\ ${ }^{3}$ Program Studi Profesi Bidan, Fakultas Kedokteran, Universitas Brawijaya
}

\begin{abstract}
Woman in third trimester of pregnancy level most likely has high an anxiety due to worry about labor process and fetus born condition. If the anxiety is continuously allowed to occur, it will have negative impact on both mother and fetus. Women will experience longer labor process due to the weakness of the uterine muscle contractions. Anxiety can also increase the risk of low birth weight (LBW) and pre-term birth. In addition, excessive anxiety can also affect the relationship between mother and fetus, while this relationship should well interwoven during pregnancy to support cognitive, motor and social growth of children after birth. This relationship is known as prenatal attachment. This study aimed to determine the correlation between the anxiety of pregnant women in facing labor with prenatal attachment score. This study used a quantitative research design with cross sectional method and used Purposive Sampling. This study used 72 respondents starting in December 2018 to January 2019, using the Hamilton Anxiety Rating Scale (HARS) instrument and the Prenatal Attachment Inventory (PAI). The statistic test used non-parametric test, Kendall Tau. Results shows the p-value $0.019(<0.05)$ and the correlation coefficient is -0.250 which means the higher anxiety level of pregnant women, the lower of prenatal attachment score. The research hopefully can be representation for care provider to keep take care of woman's psychology with increasing their prenatal attachment that can improve mother and fetus health.
\end{abstract}

Keywords : pregnancy, anxiety, prenatal attachment

\section{ABSTRAK}

Ibu hamil trimester III cenderung mengalami kecemasan yang tinggi karena khawatir memikirkan proses persalinan serta kondisi janin yang akan dilahirkan. Adapun faktor yang menjadi penyebab kecemasan ibu dapat berupa pengalaman persalinan yang buruk sebelumnya. Selain itu, faktor lainnya dapat berupa usia ibu, gravida dan tingkat pendidikan serta status kesehatan. Jika kecemasan ibu terus terjadi, maka dapat mempengaruhi hubungan ibu dengan janin yang dikenal dengan prenatal attachment. Prenatal attachment didefinisikan sebagai hubungan yang diperlihatkan dalam bentuk tindakan nyata dengan melakukan interaksi dengan janin, mendeskripsikan karakteristik janin, menghindari perilaku yang membahayakan janin dan memenuhi segala kebutuhan janin. Kecemasan dalam kehamilan kecemasan dapat mengakibatkan menurunnya kontraksi uterus, sehingga persalinan akan bertambah lama, peningkatan insidensi atonia uteri, laserasi perdarahan, 
infeksi, kelelahan ibu, dan syok, sedangkan pada bayi dapat meningkatkan resiko kelahiran prematur dan BBLR. Penelitian ini memiliki tujuan utama yaitu untuk mengetahui hubungan antara tingkat kecemasan pada ibu hamil trimester III dengan skor prenatal attachment. Penelitian ini menggunakan desain penelitian kuantitatif, metode cross sectional dan menggunakan purposive sampling. Penelitian ini menggunakan 72 responden yang dimulai pada bulan Desember 2018 hingga Januari 2019 dengan instrumen Hamilton Anxiety Rating Scale (HARS) dan Prenatal Attachment Inventory (PAI). Uji statistik ini menggunakan non parametrik yaitu Kendall Tau. Hasil yang didapatkan menunjukkan p-value 0,019 $(<0.05)$ dan koefisien korelasi sebesar -0.250 yang berarti semakin tinggi tingkat kecemasan ibu hamil, maka skor prenatal attachment ibu semakin rendah. Penelitian ini diharapkan dapat menjadi gambaran bagi tenaga kesehatan, khususnya bidan untuk tetap memperhatikan kondisi psikologis ibu dengan melakukan pengukuran skor prenatal attachment sehingga dapat meningkatkan kesehatan ibu dan janin.

Kata kunci: kehamilan, kecemasan, prenatal attachment

*Korespondensi: Rizkatul Baro'ah. Surel : rizkatulbaroah@gmail.com

\section{PENDAHULUAN}

dari pengalaman yang tidak
menyenangkan yang ditandai dengan perasaan gelisah, timbul ketakutan karena akan menghadapi ancaman yang akan dialami oleh individu dan disertai dengan rangsangan fisiologis ${ }^{1}$. Ibu hamil trimester III cenderung mengalami kecemasan yang tinggi karena khawatir memikirkan proses persalinan serta kondisi janin yang akan dilahirkan. Data yang didapatkan pada tahun 2009 menunjukkan bahwa dari 30 ibu hamil di Kota Malang, 67,8\% pada trimester III mengalami kecemasan ${ }^{2}$. Jika kecemasan ini terus menerus terjadi pada ibu terutama pada saat trimester III, maka dapat menyebabkan dampak yang negatif untuk ibu maupun janinnya, baik itu pada saat persalinan, maupun setelah persalinan. Adapun berbagai dampak kecemasan yang dapat terjadi adalah meningkatkan resiko kejadian BBLR dan kelahiran prematur ${ }^{3}$. Selain itu, dampak yang terjadi pada ibu adalah melemahnya kontraksi otot rahim saat proses persalinan karena terjadinya pelepasan hormon katekolamin dan adrenalin yang dapat menghambat pengeluaran hormon oksitosin. Melemahnya kontraksi otot rahim dapat menyebabkan partus lama sehingga dapat meningkatkan kejadian infeksi dan kelehahan pada ibu ${ }^{4}$. Selain itu, kecemasan yang terjadi pada ibu hamil juga berkaitan dengan depresi postpartum karena terjadinya gangguan emosional ibu yang tidak stabil, baik pada sebelum persalinan hingga setelah persalinan. Kecemasan yang terus menerus terjadi pada masa kehamilan juga dapat mempengaruhi hubungan antara ibu dan lingkungan sekitarnya, termasuk dengan janinnya. Hubungan antara ibu dan janin ini harus terjalin dengan baik selama kehamilan, sebab hal tersebut dapat memberikan dampak yang positif untuk ibu dan janin, baik pada saat persalinan, maupun setelah persalinan. Hubungan inilah yang dikenal dengan prenatal attachment. Prenatal attachment adalah hubungan yang diperlihatkan dalam bentuk tindakan yang nyata dengan melakukan interaksi antara ibu dengan janinnya, mendeskripsikan karakteristik janin, menghindari perilaku yang dapat membahayakan janin dan memenuhi segala kebutuhan janin ${ }^{5}$.

Adapun manfaat dari skor prenatal attachment yang tinggi adalah 
dapat menurunkan kejadian BBLR, prematur dan IUGR serta dapat menunjang pertumbuhan kognitif, motorik dan sosial anak setelah dilahirkan ${ }^{6}$. Manfaat lain yang dari tingginya skor prenatal attachment adalah adalah dapat menurunkan resiko kejadian baby blues atau bahkan depresi postpartum. Jika kejadian depresi postpartum menurun, maka proses bonding attachment juga akan lebih mudah dilakukan ${ }^{7}$. Instrumen yang digunakan dalam pengukuran prenatal attachment ini adalah kuisioner Prenatal Attachment Inventory (PAI) versi Arabia. Seseorang yang mengalami kecemasan berat akan mempengaruhi proses berpikir dan perilakunya, termasuk ibu hamil. Jika ibu merasa cemas dalam menghadapi persalinannya, maka pola pikir yang terbentuk akan negatif dan melahirkan perilaku yang negatif pula pada janin karena hanya terfokus pada dirinya sendiri.

\section{METODE PENELITIAN}

\section{Rancangan Penelitian}

Variabel bebas (independen) yang digunakan yaitu tingkat kecemasan pada ibu hamil trimester III, sedangkan variabel terikat (dependent) yaitu skor prenatal attachment. Adapun metode yang digunakan adalah cross sectional dengan teknik pengambilan sampel non probability sampling yaitu purposive sampling.

\section{Sumber Data}

Sumber data penelitian diperoleh melalui pengisian kuesioner Hamilton Anxiety Rating Scale (HARS) dan Prenatal Attachment Inventory (PAI) versi Arabia. HARS yang digunakan adalah sesuai standar (tidak dimodifikasi) untuk melihat tingkat kecemasan ibu hamil TM 3, sedangkan PAl versi arabia adalah untuk melihat skor prenatal attachment ibu.

\section{Sasaran Penelitian}

Sasaran dalam penelitian ini adalah ibu hamil yang periksa hamil di PMB Rina. Sampel adalah ibu yang usia kehamilan minimal 35 minggu, pendidikan terakhir minimal SMP, maksimal telah melahirkan 4 orang anak dan berencana melahirkan secara normal serta tidak memiliki komplikasi pada kehamilannya.

\section{Pengembangan Instrumen dan Teknik Pengumpulan Data}

Instrumen penelitian yang digunakan dalam penelitian meliputi pengisian kuisioner kecemasan yang dinamakan dengan HARS dan kusioner Prenatal Attachment Inventory (PAI) yang terdiri dari 25 pernyataan. Sebelum pengisian kusioner, peneliti melihat rekam medis atau buku KIA yang dibawa oleh responden, kemudian menentukan responden berdasarkan kriteria inklusi. Dalam kuisioner tersebut pula, responden mengisi identitas seperti nama, usia, paritas, pendidikan dan pekerjaan.

\section{Teknik Analisis Data}

Analisis data pada penelitian ini menggunakan uji statistik Kendall Tau. Nilai $\alpha \leq 0,05$ dengan tingkat kepercayaan 95\%. Data diolah menggunakan SPSS. Penelitian ini telah melalui proses ethical clearance dan telah mendapat surat etik resmi dari Komisi Etik Fakultas Kedokteran Universitas Brawijaya Malang pada tanggal 01 Desember 2019 dengan nomor surat 362/EC/KEPK-S1$\mathrm{KB} / 12 / 2018$. 
HASIL PENELITIAN

Tabel 1. Karakteristik Responden

\begin{tabular}{|c|c|c|}
\hline Usia lbu & $\mathbf{N}$ & $\%$ \\
\hline $21-25$ tahun & 26 & $36 \%$ \\
\hline $26-30$ tahun & 19 & $26 \%$ \\
\hline $31-35$ tahun & 27 & $38 \%$ \\
\hline (UK) & $\mathbf{N}$ & $\%$ \\
\hline 35 Minggu & 13 & $18 \%$ \\
\hline 36 Minggu & 18 & $25 \%$ \\
\hline 37 Minggu & 22 & $31 \%$ \\
\hline 38 Mingqu & 9 & $13 \%$ \\
\hline 39 Minggu & 4 & $6 \%$ \\
\hline 40 Minggu & 4 & $6 \%$ \\
\hline 41 Minggu & 2 & $3 \%$ \\
\hline Paritas & $\mathbf{N}$ & $\%$ \\
\hline Primigravda & 29 & $40 \%$ \\
\hline Multigravida & 43 & $60 \%$ \\
\hline Pendidikan & $\mathbf{N}$ & $\%$ \\
\hline SMA & 48 & $67 \%$ \\
\hline D1 & 2 & $3 \%$ \\
\hline D3 & 2 & $3 \%$ \\
\hline S1 & 13 & $18 \%$ \\
\hline S1 & 7 & $10 \%$ \\
\hline Pekerjaan & $\mathbf{N}$ & $\%$ \\
\hline Ibu Rumah Tangga & 42 & $58 \%$ \\
\hline Karyawan Swasta & 3 & $4 \%$ \\
\hline Wiraswasta & 11 & $15 \%$ \\
\hline Guru & 9 & $13 \%$ \\
\hline Mahasiswa & 1 & $1 \%$ \\
\hline Dosen & 6 & $8 \%$ \\
\hline
\end{tabular}

Berdasarkan hasil penelitian, sebagian besar usia responden adalah usia 31-35 tahun yaitu sebanyak 27 orang (38\%) dan paling sedikit berusia 26-30 tahun sebanyak 19 orang (26\%).

Jika dilihat dari segi usia kehamilan, sebagian responden memiliki usia kehamilan 37 minggu sebanyak 22 orang (31\%) dan paling sedikit memiliki usia kehamilan 41 minggu yaitu sebanyak 2 orang (3\%). Jika dilihat dari paritas, sebagian besar responden adalah ibu multigravida yaitu sebanyak 43 orang $(60 \%)$.
Tidak hanya itu, sebagian besar responden adalah menempuh pendidikan terakhir SMA yaitu sebanyak 48 orang $(67 \%)$ dan yang paling sedikit menempuh pendidikan terakhir D1 dan D3 yaitu masingmasing sebanyak 2 orang (3\%). Jika dilihat dari segi pekerjaan, sebagian besar responden tidak bekerja atau sebagai ibu rumah tangga yaitu sejumlah 42 orang $(58 \%)$ sedangkan jenis pekerjaan yang paling sedikit yaitu sebagai mahasiswa yaitu sejumlah 1 orang(1\%). 
Tabel 2. Karakteristik Responden berdasarkan Tingkat Kecemasan

\begin{tabular}{ccc}
\hline Tingkat Kecemasan & N & $\%$ \\
\hline Tidak Ada Kecemasan & 15 & $21 \%$ \\
Kecemasan Ringan & & $51 \%$ \\
Kecemasan Sedang & 37 & $17 \%$ \\
Kecemasan Berat & 12 & $11 \%$ \\
\hline
\end{tabular}

Berdasarkan hasil penelitian, sebagian besar responden didapati mengalami kecemasan ringan yaitu sejumlah 37 orang (51\%), kemudian diikuti responden yang tidak mengalami kecemasan sejumlah 15 orang (21\%) sedangkan kecemasan berat dialami oleh sebagian kecil responden yaitu sejumlah 8 orang $(11 \%)$.

Tabel 3. Karakteristik Responden berdasarkan Skor Prenatal Attachment

Prenatal Attachment

Skor Tinggi

Skor Sedang

Skor Rendah

$\mathbf{N}$

33

30

9

$\%$

$46 \%$

$42 \%$

$13 \%$

\section{Analisi Bivariat}

Tabel 4. Hubungan Antara Tingkat Kecemasan dengan Skor Prenatal Attachment

\begin{tabular}{|c|c|c|c|c|}
\hline \multirow{2}{*}{ Tingkat Kecemasan } & \multicolumn{3}{|c|}{ Skor Prenatal Attachment } & \multirow{2}{*}{ Total } \\
\hline & Tinggi & Sedang & Rendah & \\
\hline Tidak ada Kecemasan & $8(11 \%)$ & $6(8 \%)$ & $1(2 \%)$ & $15(21 \%)$ \\
\hline Kecemasan Ringan & $20(28 \%)$ & $14(20 \%)$ & $3(4 \%)$ & $37(51 \%)$ \\
\hline Kecemasan Sedang & $5(7 \%)$ & $5(7 \%)$ & $2(3 \%)$ & $12(17 \%)$ \\
\hline Kecemasan Berat & $0(0 \%)$ & $5(7 \%)$ & $3(4 \%)$ & $8(11 \%)$ \\
\hline Total & $33(46 \%)$ & $30(42 \%)$ & $9(13 \%)$ & $72(100 \%)$ \\
\hline
\end{tabular}

Berdasarkan uji statistic Kendall Tauu, didapatkan bahwa nilai $p$ value dalam penelitian ini yaitu 0,019 dengan ketentuan nilai signifikansi $<0.05$ sehingga dapat diartikan bahwa adanya korelasi antara tingkat kecemasan ibu hamil pada saat trimester III dengan skor prenatal attachment.
Nilai koefisien korelatif didapatkan sebesar -0,250 yaitu arah negatif menandakan bahwa semakin tinggi tingkat kecemasan ibu hamil dalam menghadapi persalinan, maka skor prenatal attachment ibu semakin rendah. Namun jika dilihat dari hubungan keeratannya, masih bersifat lemah. 


\section{PEMBAHASAN}

Kecemasan ibu yang berlebihan selama kehamilan dapat mempengaruhi kognitif, perilaku dan interaksi ibu terhadap janinnya atau yang dikenal dengan prenatal attachment. Jika ibu semakin cemas memikirkan proses persalinannya, maka interaksi ibu dengan janinnya juga tidak maksimal sehingga skor prenatal attachmentnya menjadi semakin rendah. Berdasarkan uji statistik Kendall Tau yang telah dilakukan, didapatkan hasil $p$-value $=$ $0,019(<0,05)$. Nilai hitung koefisien korelasi didapatkan hasil $(-0,250)$ yaitu arah negatif menandakan bahwa semakin tinggi tingkat kecemasan ibu hamil dalam menghadapi persalinan, maka skor prenatal attachment ibu semakin rendah. Namun jika dilihat dari segi hubungan keeratannya, hubungan keduanya masih tergolong lemah.

Hasil penelitian yang dilakukan kepada 72 responden, sebagaian besar responden mengalami kecemasan ringan. Kecemasan ringan yang dialami oleh ibu disebabkan karena berbagai faktor misalnya usia, paritas, berbagai kegiatan yang pernah diikutinya selama kehamilan misalnya kelas ibu hamil dan senam hamil serta adanya dukungan sosial dari keluarga, termasuk suami. Dukungan tersebut dapat terlihat dari keikutsertaan suami dalam mendampingi ibu saat melakukan pemeriksaan (antenatal care) ${ }^{8}$.

Selain itu, hasil penelitian ini juga menununjukkan bahwa sebagian besar responden memiliki skor prenatal attachment yang tinggi. Hal tersebut dikaitkan dengan berbagai faktor misalnya usia ibu, usia kehamilan, dukungan keluarga dan penggunaan USG ${ }^{9}$. ibu yang telah mengetahui jenis kelamin janinnya melalui USG akan berdampak pada intensitas percakapan, perencanaan dan angan-angan ibu dalam menyambut janinnya sehingga dapat meningkatkan skor prenatal attachmentnya pula $^{10}$. Selain itu, faktor yang juga mempengaruhi skor prenatal attachment adalah kondisi psikologis seseorang. Faktor psikologis tersebut dapat berupa kepribadian ibu, stres dan kecemasan ${ }^{11}$. Pada penelitian yang dilakukan oleh Kwon MK menunjukkan bahwa adanya korelasi antara kondisi psikologis seseorang yaitu depresi dengan skor prenatal attachment, tetapi tidak cukup signifikan. Hal tersebut terjadi karena dampak dari kondisi psikologis ibu yang terganggu tidak dapat diabaikan karena berkaitan dengan kesehatan janin ${ }^{12}$. Hasil penelitian ini menunjukkan bahwa faktor psikologis seperti kecemasan dalam menghadapi persalinan bukanlah faktor yang dominan dalam mempengaruhi skor prenatal attachment. Penelitian yang dilakukan oleh Kwon (2011) menunjukkan bahwa hal yang paling penting dalam prenatal attachment adalah dukungan sosial dari keluarga ${ }^{12}$. Dukungan keluarga tersebut dapat membuat ibu merasa lebih nyaman dan merasa diperhatikan sehingga akan mempengaruhi hubungan yang positif juga antara ibu dan janin sehingga skor prenatal attachmennya menjadi lebih tinggi. Adapun beberapa faktor lain yang dapat menurunkan skor prenatal attachment adalah pekerjaan dan graviditas. Ibu yang pertama kali hamil (primigravida) akan cenderung menyambut janinnya dengan rasa suka cita yang lebih tinggi (excited) dan merasa memiliki peran baru menjadi calon ibu dengan menunjukkan pikiran dan perilaku ibu yang sangat fokus memikirkan kondisi janinnya serta lebih 
sering mengajak janin untuk berinteraksi dibandingkan dengan ibu yang multigravida ${ }^{11}$. Hal tersebut menyebabkan lebih tingginya skor prenatal attachment pada ibu primigravida. Selain itu, jika dlihat dari segi pekerjaan, ibu yang bekerja akan lebih banyak memikirkan pekerjaannya sehingga waktu untuk melakukan interaksi dengan janinnya tidak sesering dengan ibu yang tidak bekerja.

\section{SIMPULAN}

Terdapat hubungan antara tingkat kecemasan ibu hamil trimester III atau yang akan mengahadapi persalinan dengan skor prenatal attachment. Semakin tinggi tingkat kecemasan ibu hamil, maka skor prenatal attachmennya semakin rendah. Hubungan keduanya bersifat lemah yang diduga disebabkan karena graviditas, pekerjaan dan dukungan social.

\section{DAFTAR PUSTAKA}

1. Hidayati. 2008. Hubungan Senam Lansia dengan Tingkat Kecemasan Pada Lansia di PSTW Budi Luhur Bantul Yogyakarta. Yogyakarta: Universitas Muhamadiyah Yogyakarta.

2. Maimunah, S. 2009. Kecemasan Ibu Hamil Menjelang Persalinan Pertama. Malang: Humanity, 1 (5).

3. Ranita, B dan Hendri. 2016. Pengaruh Belly Dance Terhadap Tingkat Kecemasan Ibu Hamil Primigravida Trimester III di BPM Ranting 3 Kota Semarang.
4. Difarissa, R., Jendariah T., Didiek $P$ 2016. Hubungan Tingkat Kecemasan dan Lama Partus Kala 1 Fase Aktif Pada Primigravida. Pontianak: Jurnal Cerebellum.

5. Ossa, Luis B., Lilian F. 2011. Prenatal Attachment and Associated Factor during the Third Trimester of Pregnancy in

Temuco Chile. Chile: Midwifery Elsevier

6. Maddahi, S., Makhrokh D., Monirsadat K., Afeteh T. 2016. Correlation of Maternal-Fetal Attachment and Health Practices During Pregnancy with Neonatal Outcomes. Iran: University Medical Science Tehran.

7. Goecke., Voigst., Faschingbauer., Spangler., Beckmann., Beetz. 2012. The Association Of Prenatal Attachment And Perinatal Factors With Pre- And Postpartum Depression In First-Time Mothers. Maternal Fetal Medicine.

8. Rahimah. 2015. Hubungan Dukungan Keluarga Dengan Tingkat Kecemasan Ibu Hamil Primigravida Dalam Menghadapi Persalinan di Klinik Pratama Umum Pelita Hati Banguntapan. Yogyakarta: Universitas Asisiyah Yogyakarta.

9. Sukriani, W dan Endang K. 2018. Faktor yang Berhubungan dengan Prenatal Attachment Pada Ibu Hamil. Yogyakarta: Universitas Aisiyah Yogyakarta.

10.Lahann. 2008. An Examination of Maternal-fetal Attachment in Singleton and Twin 
Pregnancies.USA: Capella University.

11. Hassan, N dan Fawzia M. 2017 Predictors of Maternal Fetal Attachment Among Pregnant Women. Egypt: Alexandria University.

12. Kwon, K dan Kyung S. 2011. Relationship of Prenatal Stress and Depression to Maternal Fetal Attachment and Fetal Growth. Seoul: Seoul National University 